Limnological Review (2011) 11, 1: 15-23

DOI 10.2478/v10194-011-0023-3

\title{
Eutrophication parameters and Carlson-type trophic state indices in selected Pomeranian lakes
}

\author{
Anna Jarosiewicz ${ }^{1 \star}$, Dariusz Ficek ${ }^{2}$, Tomasz Zapadka² \\ ${ }^{1}$ Institute of Biology and Environmental Protection, Pomeranian Academy in Słupsk, Arciszewskiego 22B, 76-200 Słupsk, Poland; \\ *e-mail: jarosiewicza@poczta.onet.pl \\ ${ }^{2}$ Institute of Physics, Pomeranian Academy in Słupsk, Arciszewskiego 22B, 76-200 Słupsk, Poland
}

\begin{abstract}
The objective of the study (2007-09) was to determine the current trophic state of eight selected lakes - Rybiec, Niezabyszewskie, Czarne, Chotkowskie, Obłęże, Jasień Południowy, Jasień Północny, Jeleń - based on Carlson-type indices (TSIs) and, to examine the relationship between the four calculated trophic state indices: TSI(SD), TSI(Chl), TSI(TP) and TSI(TN). Based on these values, it can be claimed that the trophy level of the lakes are within the mesotrophic and eutrophic states. It was observed that the values of the TSI(TP) in the analysed lakes are higher than the values of the indices calculated on the basis of the other variables. Moreover, the differences between the indices for particular lakes, suggest that in none of the analysed lakes is phosphorus a factor which limits algal productivity.
\end{abstract}

Key words: eutrophication, trophic state index, lake, phosphorus, nitrogen

\section{Introduction}

Determining the trophic condition of a lake is an important step in the scientific assessment of each lake. It enables us to describe the following: (i) the abiotic and biotic condition of waterbodies; (ii) the relations between chemical and biological parameters; and (iii) the condition of the lake in relation to human needs or values (Carlson and Simpson 1996; Matthews et al. 2002; Wetzel 2001). Descriptions of trophic states are made from examination of several diverse criteria, such as concentration of nutrients, productivity, faunal and floral quantity and quality, oxygen availability, and lake morphometry. Unfortunately, a multiparameter trophy index is difficult in usage. Therefore, Carlson (1977) formulated the trophic state indices (TSIs) as a quantitative measure of the degree of lake eutrophication. The indices are calculated using three parameters: log-transformed Secchi disk transparency, concentration of chlorophyll and total phosphorus in a lake. In theory the maximum limit of TSIs value is indefinite, but in practice, the scale of the index is from 0 to 100, and corresponds generally to transpar- ency extremes $(0.06 \mathrm{~m}$ to $64 \mathrm{~m})$ observed in nature (Carlson 1977). Each 10 units within this system represents a half decrease in Secchi depth, a one-third increase in chlorophyll concentration and a doubling of total phosphorus amount (Dodds et al. 1998). Generally the TSIs value below 40 corresponds to oligotrophy, between 40 and 60 - mesotrophy, from 60 to 80 - eutrophy, and above 80 - hypertrophy of the lake (Bajkiewicz-Grabowska 2007).

Kratzer and Brezonik (1981) introduced an additional Carlson-type index based on total nitrogen concentration, as a part of the research effort to investigate seasonal nitrogen limitation in lakes.

The trophic state indices proposed by Carlson (1977) and Kratzer and Brezonik (1981) are frequently used to describe the condition of surface waters and, therefore the objective of the study was to determine the current trophic status of eight selected lakes - Rybiec, Niezabyszewskie, Czarne, Chotkowskie, Obłęże, Jasień Południowy (Jasień S), Jasień Północny (Jasień $\mathrm{N}$ ), Jelen - based on TSIs and, to examine the relationship between the four calculated trophic state indices: TSI(SD), TSI(Chl), TSI(TP) and TSI(TN). 


\section{Materials and methods}

The lakes described in our article are located in north Poland (Pomerania Lakeland), between the Pomeranian rivers Wieprza and Łupawa (Fig. 1).

They differ in morphometric features, catchment area and hydrological type (Table 1). Two lakes - Rybiec and Niezabyszewskie (maximum depth 2.8 and $5.3 \mathrm{~m}$, respectively) - are non-stratified, while the others are characterized by thermal stratification dur-

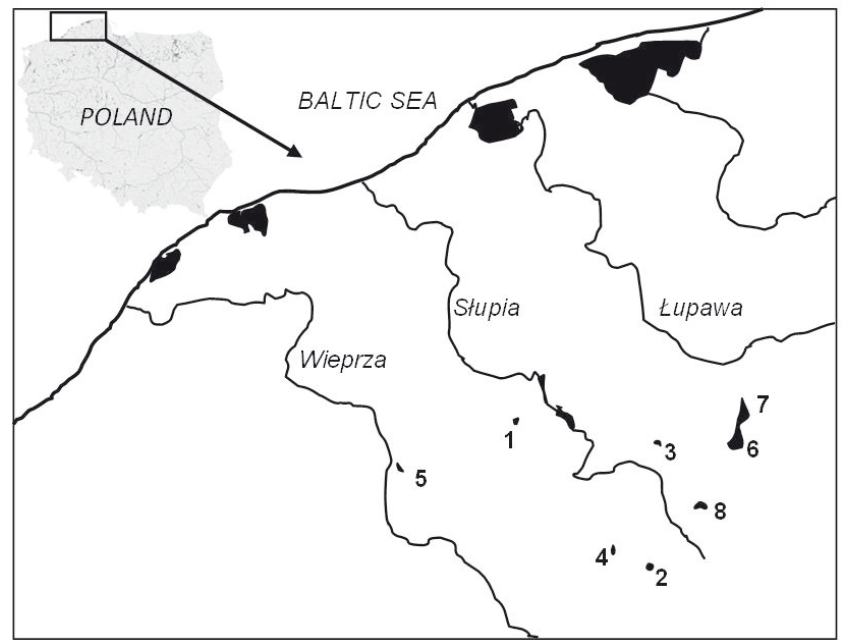

Fig. 1. Location of lakes: 1 - Rybiec, 2 - Niezabyszewo, 3 - Czarne, 4 - Chotkowskie, 5 - Obłęże, 6 - Jasień S, 7 - Jasień N, 8 - Jeleń ing the summer. There are flow lakes, groundwater dependent lakes, and outflow lakes. The lakes differ in catchment area usage, and therefore in anthropopressure.

Our study is based on water quality data collected from 2007 to 2009. Measurements of water quality were conducted in lakes at one sampling site, located above the deepest part of each lake. Measurements were usually performed in monthly intervals, and, depending on the lake, there were from 6 to 19 investigations (Table 2), during one (Rybiec, Niezabyszewo, Jeleń), or two (Czarne, Chotkowskie, Obłęże, Jasień S and Jasień N) limnological cycles.

The physical-chemical analyses of water were done with standard methods. Concentration of chlorophyll $a$ was determined spectrophotometricially according to the standard method in cold water with 90\% acetone (Jeffrey and Humphrey 1975). Water transparency was measured using $0.3 \mathrm{~m}$ Secchi disks (SD). Concentrations of total phosphorus (TP) and total nitrogen (TN) were determined after their oxidation to nitrates and phosphates by autoclaving and digestion in perichloric acid according to respective colorimetric methods described in Hermanowicz et al. (1976), using spectrophotometer SP-830 plus Metertech.

Trophic state indices (TSIs) were calculated for the lakes as a whole, using the equations described by

Table 1. Basic morphological and hydrological parameters, average concentration of nutrients and chlorophyll $a$ in the surface water layer, and Secchi disk visibility during the study period

\begin{tabular}{|c|c|c|c|c|c|c|c|c|c|c|c|c|c|}
\hline \multirow[t]{2}{*}{ No. } & \multirow[t]{2}{*}{ Lake } & \multirow[t]{2}{*}{ Location } & $\begin{array}{c}\text { Surface } \\
\text { area }\end{array}$ & Volume & $\begin{array}{l}\text { Max. } \\
\text { depth }\end{array}$ & $\begin{array}{l}\text { Mean } \\
\text { depth }\end{array}$ & \multirow{2}{*}{$\begin{array}{c}\text { Type of water } \\
\text { balance of } \\
\text { lake }\end{array}$} & \multirow{2}{*}{$\begin{array}{l}\text { Land } \\
\text { use }\end{array}$} & $\mathrm{SD}^{*}$ & $\mathrm{TN}^{*}$ & $\mathrm{TP}^{*}$ & TN:TP* & Chl a* \\
\hline & & & $\mathrm{km}^{2}$ & $\mathrm{~m}^{3} \cdot 10^{6}$ & $\mathrm{~m}$ & $\mathrm{~m}$ & & & $\mathrm{~m}$ & $\mathrm{mg} \mathrm{dm}^{-3}$ & $\mathrm{mg} \mathrm{dm}^{-3}$ & & $\mathrm{mg} \mathrm{m}^{-3}$ \\
\hline 1 & Rybiec & $\begin{array}{l}54^{\circ} 17.8^{\prime} \mathrm{N} \\
17^{\circ} 09.5^{\prime} \mathrm{E} \\
\end{array}$ & 0.142 & 0.227 & 2.8 & 1.6 & outflow lake & $\mathrm{F}, \mathrm{A}$ & 0.8 & 1.90 & 0.18 & 10.4 & 97.1 \\
\hline 2 & Niezabyszewo & $\begin{array}{l}54^{\circ} 07.7^{\prime} \mathrm{N} \\
17^{\circ} 25.8^{\prime} \mathrm{E} \\
\end{array}$ & 0.484 & 1.294 & 5.3 & 2.7 & $\begin{array}{c}\text { without } \\
\text { outflow lake }\end{array}$ & $\mathrm{F}, \mathrm{A}, \mathrm{M}$ & 1.3 & 1.08 & 0.17 & 6.7 & 26.8 \\
\hline 3 & Czarne & $\begin{array}{l}54^{\circ} 16.5^{\prime} \mathrm{N} \\
17^{\circ} 26.5^{\prime} \mathrm{E} \\
\end{array}$ & 0.180 & 0.954 & 14.0 & 5.3 & $\begin{array}{c}\text { without } \\
\text { outflow lake }\end{array}$ & $F$ & 2.2 & 1.08 & 0.12 & 9.9 & 6.5 \\
\hline 4 & Chotkowskie & $\begin{array}{l}54^{\circ} 09.1^{\prime} \mathrm{N} \\
17^{\circ} 21.6^{\prime} \mathrm{E}\end{array}$ & 0.567 & 3.058 & 10.3 & 5.4 & flow lake & $A, M$ & 1.9 & 1.45 & 0.20 & 8.1 & 31.2 \\
\hline 5 & Obłęże & $\begin{array}{l}54^{\circ} 14.7^{\prime} \mathrm{N} \\
16^{\circ} 55.1^{\prime} \mathrm{E}\end{array}$ & 0.624 & 3.728 & 8.9 & 6.0 & flow lake & $\mathrm{F}, \mathrm{A}, \mathrm{O}$ & 2.3 & 1.00 & 0.17 & 6.1 & 15.3 \\
\hline 6 & Jasień S & $\begin{array}{l}54^{\circ} 16.7^{\prime} \mathrm{N} \\
17^{\circ} 35.8^{\prime} \mathrm{E} \\
\end{array}$ & 3.367 & 26.052 & 22.6 & 7.8 & flow lake & $\mathrm{F}, \mathrm{A}, \mathrm{O}$ & 2.6 & 1.09 & 0.17 & 7.4 & 12.6 \\
\hline 7 & Jasień N & $\begin{array}{l}54^{\circ} 18.5^{\prime} \mathrm{N} \\
17^{\circ} 37.3^{\prime} \mathrm{E} \\
\end{array}$ & 2.405 & 21.996 & 32.2 & 9.1 & flow lake & $\mathrm{F}, \mathrm{A}, \mathrm{O}$ & 3.4 & 1.08 & 0.13 & 8.7 & 6.7 \\
\hline 8 & Jeleń & $\begin{array}{l}54^{\circ} 12.0^{\prime} \mathrm{N} \\
17^{\circ} 31.8^{\prime} \mathrm{E}\end{array}$ & 0.889 & 8.461 & 33.2 & 9.5 & $\begin{array}{c}\text { without } \\
\text { outflow lake }\end{array}$ & $\mathrm{F}, \mathrm{A}, \mathrm{O}$ & 4.9 & 0.77 & 0.06 & 13.7 & 5.8 \\
\hline
\end{tabular}

F - forest; A - arable land; $\mathrm{M}$ - meadow; O - other

* mean annual value 
Table 2. Trophic state indices (TSIs) for all measured lakes

\begin{tabular}{|c|c|c|c|c|c|}
\hline \multicolumn{2}{|l|}{ Lake } & TSI(SD) & TSI(Chl) & TSI(TP) & $\mathrm{TSI}(\mathrm{TN})$ \\
\hline \multirow{4}{*}{ Rybiec } & $\mathrm{n}$ & \multicolumn{4}{|c|}{6} \\
\hline & Mean & 65.0 & 72.0 & 79.0 & 63.6 \\
\hline & Min/Max & $53.2 / 75.1$ & $59.3 / 83.3$ & $77.1 / 80.2$ & $59.8 / 74.1$ \\
\hline & Std. Dev. & 9.9 & 10.1 & 1.3 & 5.4 \\
\hline \multirow{4}{*}{ Niezabyszewo } & $\mathrm{n}$ & \multicolumn{4}{|c|}{7} \\
\hline & Mean & 57.1 & 60.5 & 77.8 & 55.5 \\
\hline & Min/Max & $48.0 / 65.1$ & $49.8 / 70.7$ & $74.4 / 81.8$ & $53.2 / 57.4$ \\
\hline & Std. Dev. & 5.4 & 7.9 & 3.3 & 1.8 \\
\hline \multirow{4}{*}{ Czarne } & $\mathrm{n}$ & \multicolumn{4}{|c|}{12} \\
\hline & Mean & 48.7 & 48.4 & 72.5 & 55.3 \\
\hline & Min/Max & $45.7 / 53.2$ & $41.5 / 58.4$ & $65.4 / 79.0$ & $49.1 / 61.7$ \\
\hline & Std. Dev. & 2.6 & 4.5 & 3.9 & 3.5 \\
\hline \multirow{4}{*}{ Chotkowskie } & $\mathrm{n}$ & \multicolumn{4}{|c|}{19} \\
\hline & Mean & 52.5 & 60.7 & 79.1 & 58.3 \\
\hline & Min/Max & $38.3 / 61.5$ & $34.7 / 75.1$ & $71.0 / 86.1$ & $47.0 / 61.9$ \\
\hline & Std. Dev. & 6.6 & 10,5 & 5.6 & 3.8 \\
\hline \multirow{4}{*}{ Obłęże } & $\mathrm{n}$ & \multicolumn{4}{|c|}{19} \\
\hline & Mean & 49.0 & 55.6 & 78.1 & 54.1 \\
\hline & Min/Max & $37.4 / 61.5$ & $37.4 / 65.6$ & $67.9 / 97.5$ & $44.9 / 57.7$ \\
\hline & Std. Dev. & 6.5 & 7.1 & 7.5 & 8.0 \\
\hline \multirow{4}{*}{ Jasień S } & $\mathrm{n}$ & \multicolumn{4}{|c|}{14} \\
\hline & Mean & 46.8 & 52.5 & 75.9 & 54.8 \\
\hline & Min/Max & $37.4 / 52.3$ & $37.9 / 65.0$ & $65.4 / 81.8$ & $50.3 / 58.8$ \\
\hline & Std. Dev. & 4.3 & 7.7 & 4.9 & 2.6 \\
\hline \multirow{4}{*}{ Jasień N } & $\mathrm{n}$ & \multicolumn{4}{|c|}{12} \\
\hline & Mean & 43.2 & 47.9 & 73.3 & 54.2 \\
\hline & Min/Max & $35.4 / 46.8$ & $33.0 / 62.0$ & $66.4 / 77.5$ & $50.9 / 60.5$ \\
\hline & Std. Dev. & 4.2 & 7.3 & 3.3 & 3.1 \\
\hline \multirow{4}{*}{ Jeleń } & $\mathrm{n}$ & \multicolumn{4}{|c|}{9} \\
\hline & Mean & 37.3 & 46.7 & 64.8 & 50.5 \\
\hline & Min/Max & $31.9 / 40.7$ & $37.4 / 55.4$ & $59.4 / 70.4$ & $48.2 / 55.4$ \\
\hline & Std. Dev. & 3.5 & 6.4 & 4.4 & 2.3 \\
\hline
\end{tabular}

Carlson (1977) (Eqns 1 to 3) and Kretzer and Brezonik (1981) (Eqn 4):

$$
\begin{aligned}
& T S I(S D)=10\left(6-\frac{\ln S D}{\ln 2}\right), \\
& T S I(C h l)=10\left(6-\frac{(2.04-0.68) \ln C h l}{\ln 2}\right), \\
& \operatorname{TSI}(T P)=10\left(6-\frac{\ln \frac{48}{T P}}{\ln 2}\right), \\
& \operatorname{TSI}(T P)=10\left(6-\frac{\ln \frac{1.47}{T P}}{\ln 2}\right) .
\end{aligned}
$$

The variables used for these equations included SD in metres, chlorophyll $a$ (Chl) content in epilimnion (in

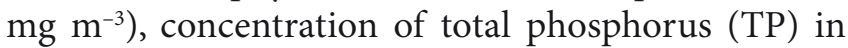
epilimnion (in $\mathrm{mg} \mathrm{m}^{-3}$ ) and concentration of total nitrogen (TN) in epilimnion (in $\mathrm{mg} \mathrm{dm}^{-3}$ ). Trophic status of lakes was estimated up on the mean annual TSIs values. The differences between indices, calculated by subtracting the monthly values of TSI(TP), TSI(TN) or TSI(SD) from TSI(Chl) as described by Carlson (1991), were used to prepare two-dimensional graphs, illustrating the biotic and abiotic relationships in lake ecosystems.

Statistical analyses were all performed using Statistica Pl 9 (StatSoft). Nonparametric variance (ANOVA followed by Kruskal-Wallis) was used to identify significant differences for lakes. 


\section{Results}

Based on each data set, collected during the study period, we calculated Carlson's TSI for the studied lakes. The lakes are significantly varied (ANOVA by Kruskal-Wallis, $\mathrm{p}<0.0001)$ according to the values of TSI(SD) TSI(Chl) and nutrients TSIs (Fig. 2). Among all the lakes (Table 2) the mean annual values of TSI(SD) ranged from about 37 (Lake Jeleń) to 65 in Lake Rybiec. In the case of TSI(Chl) it was from 47-48 in lakes Jeleń, Jasień $\mathrm{N}$ and Czarne to above 70 in Lake Rybiec. The lowest mean value of TSI(TP) was noted in Lake Jelen (64.8), whereas the highest - about 79 - in lakes Rybiec and Chotkowskie. The index based on total nitrogen concentration ranged from about 50 (Lake Jeleń) to almost 65 (Lake Rybiec).

Additionally, the calculated Carlson's trophy parameters were characterised by seasonal variability, with the range of such fluctuations being different for particular lakes. Generally, based on standard deviation values (Table 2), the smallest seasonal differences of indices were observed for Lake Jeleń, whereas the biggest changes in the indices during the study period occurred in the case of lakes Chotkowskie and Obłęże. The highest seasonal dynamics of changes was observed for the index calculated on the basis of chlorophyll $a$ concentration, such as in the case of Lake Chotkowskie, where TSI(Chl) was from 34.7 to 75.1. As a result the lake's trophy changed from oligo- to eutrophy regardless of the date of water sampling. Moreover, the changes in the TSI(Chl) trophy status appeared even during the same season. A similar situation was observed in other lakes (Rybiec, Obłęże, Jasień S and Jasień N). The more stable indices were the biogenic ones (Fig. 2).

ANOVA (by Kruskal-Wallis) applied for statistical analyses showed that also TSI values, i.e., TSI(SD), TSI(Chl), TSI(TP), TSI(TN), calculated for every studied lake were significantly different (Fig. 3). By comparing particular Carlson's indices it can be concluded (Fig. 4) that the values of the index derived from measurements of the total phosphorus concentration in the surface layer of water in the analyzed lakes are higher than the values of the indices calculated on the basis of the other variables.
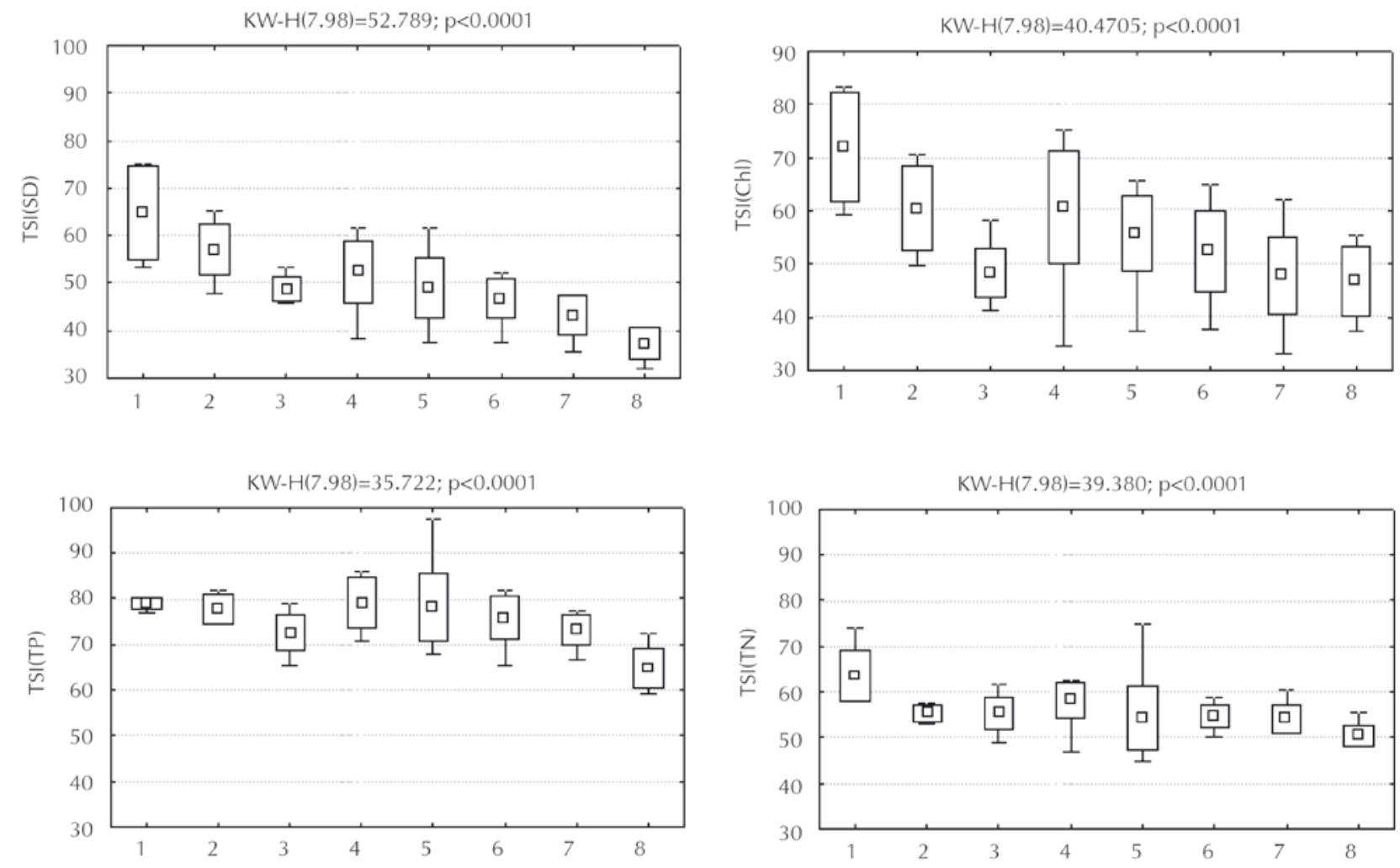

Fig.. 2. The variability of TSIs in the group of analyzed lakes; annual mean value, standard deviation (box) and minimum-maximum values (whisker); lakes: 1 - Rybiec, 2 - Niezabyszewo, 3 - Czarne, 4 - Chotkowskie, 5 - Obłęże, 6 - Jasień S, 7 -Jasień N, 8 - Jeleń 


\section{Discussion}

The Pomeranian study lakes represent a gradient of trophic state from mesotrophic to eutrophic, however there are large differences between TSIs, and therefore the estimation of lake trophic state is mostly not clear. Based on mean annual TSI values, it can be claimed that the trophy level of 6 of the analysed lakes (Niezabyszewo, Czarne, Chotkowskie, Obłęże, Jasień $\mathrm{N}$ and Jasień S Lakes) are within meso- and eutrophy. The value of the trophy, calculated on the basis

Rybiec

$\mathrm{KW}-\mathrm{H}(3.24)=10.7266 ; \mathrm{p}=0.013$

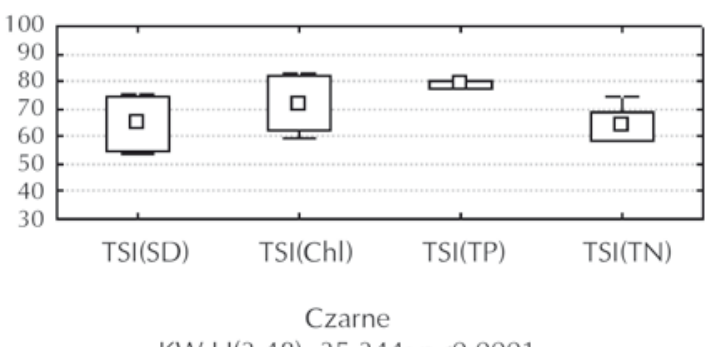

$\mathrm{KW}-\mathrm{H}(3.48)=35.344 ; \mathrm{p}<0.0001$

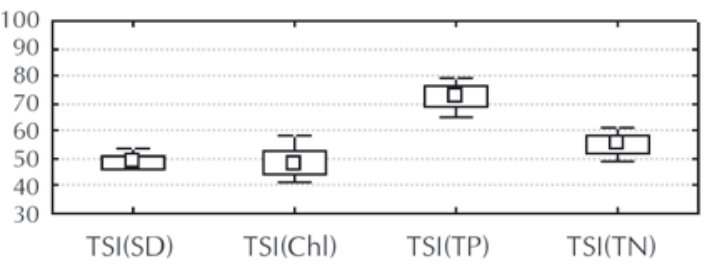

Obłęże

$\mathrm{KW}-\mathrm{H}(3.75)=46.3189 ; \mathrm{p}<0.0001$

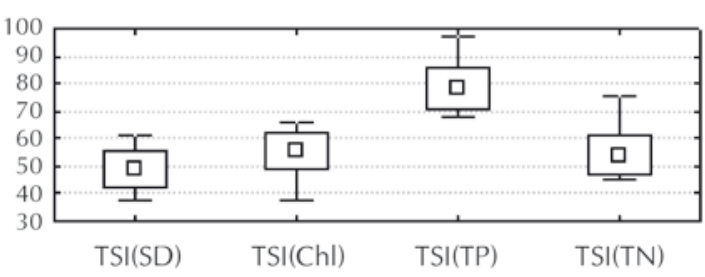

Jasień $\mathrm{N}$

$\mathrm{KW}-\mathrm{H}(3.48)=37.302 ; \mathrm{p}<0.0001$

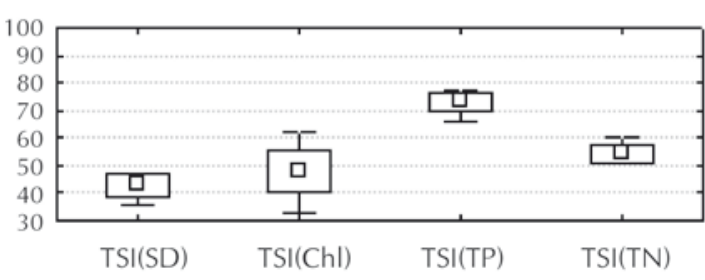

of the visibility of a Secchi disc, suggested good water transparency, typical of mesotrophic lakes $(43.2 \leq$ $\mathrm{TSI}(\mathrm{SD}) \leq 57.1)$. Likewise, the values of the parameters TSI(TN) (from 54.1 to 58.3) and TSI(Chl) (from 47.9 to 60.7) enable us to classify the lakes as mesotrophic water bodies. However, an enrichment of the trophic state of these lakes seems to be confirmed by the index derived from the concentration of total phosphorus $(72.5 \leq \mathrm{TSI}(\mathrm{TP}) \leq 79.1)$ (Table 2). Lake Rybiec proved to be the most eutrophic among the analysed water bodies. In this lake, both a very high concentration of
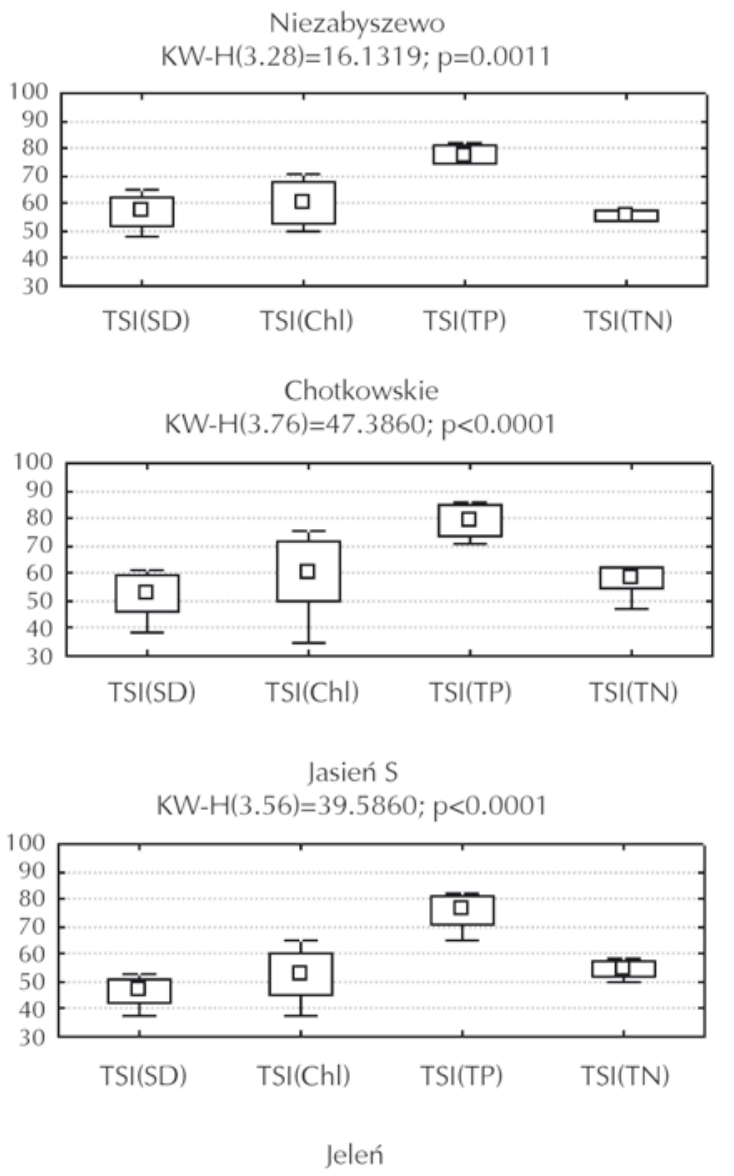

$\mathrm{KW}-\mathrm{H}(3.36)=27.382 ; \mathrm{p}<0.0001$

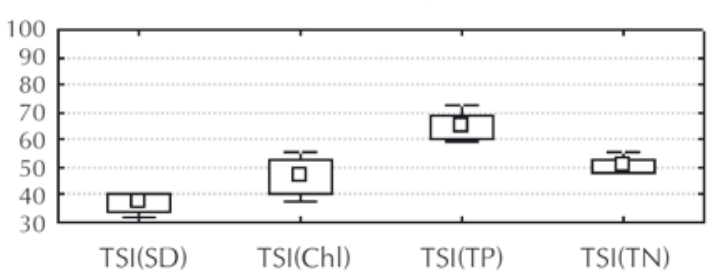

Fig. 3. The difference between TSI(SD), TSI(Chl), TSI(TP) and TSI(TN) in respective lakes; annual mean value, standard deviation (box) and minimum-maximum values (whisker) 

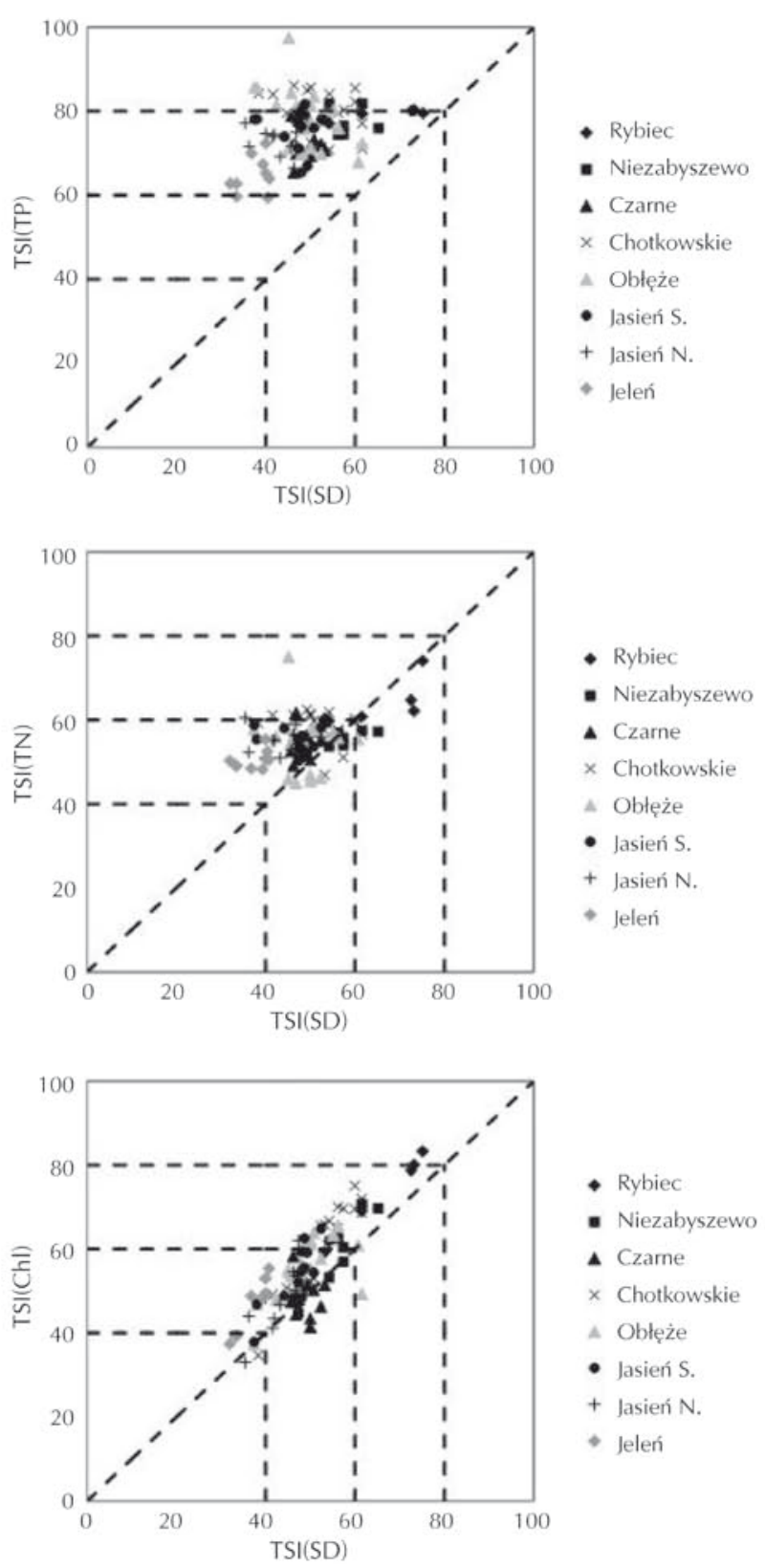

Fig. 4. Trophic state of the lakes determined with Carlson-type indices

biogenic substances and low transparency of its water classify the lake as a eutrophic one. Furthermore, high values of the parameter connected with the concentration of chlorophyll a (the summer average above 80 ) suggest that the lake is being transformed into a hypertrophic one.

In the case of Lake Jeleń, the mean annual TSIs values ranged from oligo- to eutrophy. The high transparency of Lake Jeleń water (Table 1) as well as a low TSI(SD) value (37.3) suggest its oligotrophy. The TSI(Chl) and TSI(TN) (46.7 and 50.5, respectively) suggest its mesotrophy, whereas TSI(TP) (64.8) - eutrophy.

As can be observed, higher trophic state is associated with the higher TSI(TP) values in all investigated lakes. This phenomenon has already been reported in the literature (Bajkiewicz-Grabowska 2007; Jarosiewicz and Hetmański 2009; Joniak and KuczyńskaKippen 2008; Kubiak 2003; Lenard and Solis 2009; Marszelewski 2001; Pełechata et al. 2006; Pyka et al. 2007; Zdanowski 1999). Bajkiewicz-Grabowska (2007) found out that eutrophication of lakes in the Kashubian Landscape Park was implied by high summer total phosphorus concentrations and the calculated TSI(TP) index for this group of lakes was from 65 to 89 , with the TSI(SD) value ranging from 38 to 70 . Thus, the concentration of phosphorus in these lakes was too high in the summer compared to such measures of eutrophication as water transparency and concentration of chlorophyll $a$. Pyka et al. (2007) also noticed higher values and lack of consistency of the TSI(TP) index with the other parameters in lakes in the Mazury and Suwałki Lakelands. Kubiak (2003) found that also in the case of the largest dimictic lakes of Western Pomerania, the TSI(TP), based on the total phosphorus concentration were usually higher than TSI(SD) or TSI(Chl).

In theory the calculated value of all indices should be the same, and subtracting TSI(Chl) from other TSIs will equal zero, or nearly so. In practice, there are usually deviations between TSI(Chl) and Secchi depth or phosphorus and nitrogen indices. The information about deviations between TSIs can be used to assess the degree and type of nutrient or other limitation in lakes. Generally, nitrogen limitation in lakes is observed when TSI $(\mathrm{Chl})-\mathrm{TSI}(\mathrm{TN})>0$ and TSI $(\mathrm{TN})-\mathrm{TSI}(\mathrm{TP})<0$; whereas phosphorus limitation is indicated when TSI(Chl) - TSI(TP) $>0$ and TSI (TN) - TSI(TP) > 0 (Matthews et al. 2002; Havens 1995).

In the case of each og the described lakes in this paper statistically significant deviations between the values of Carlson-type indices were noted (Fig. 3). The differences between the parameters for particular lakes (Fig. 5) suggest that in none of the analyzed lakes is phosphorus a factor which limits production of phytoplankton $(\mathrm{TSI}(\mathrm{Chl})<\mathrm{TSI}(\mathrm{TP}))$ and the average annual values of TSI(TN) - TSI(TP) are within the range 


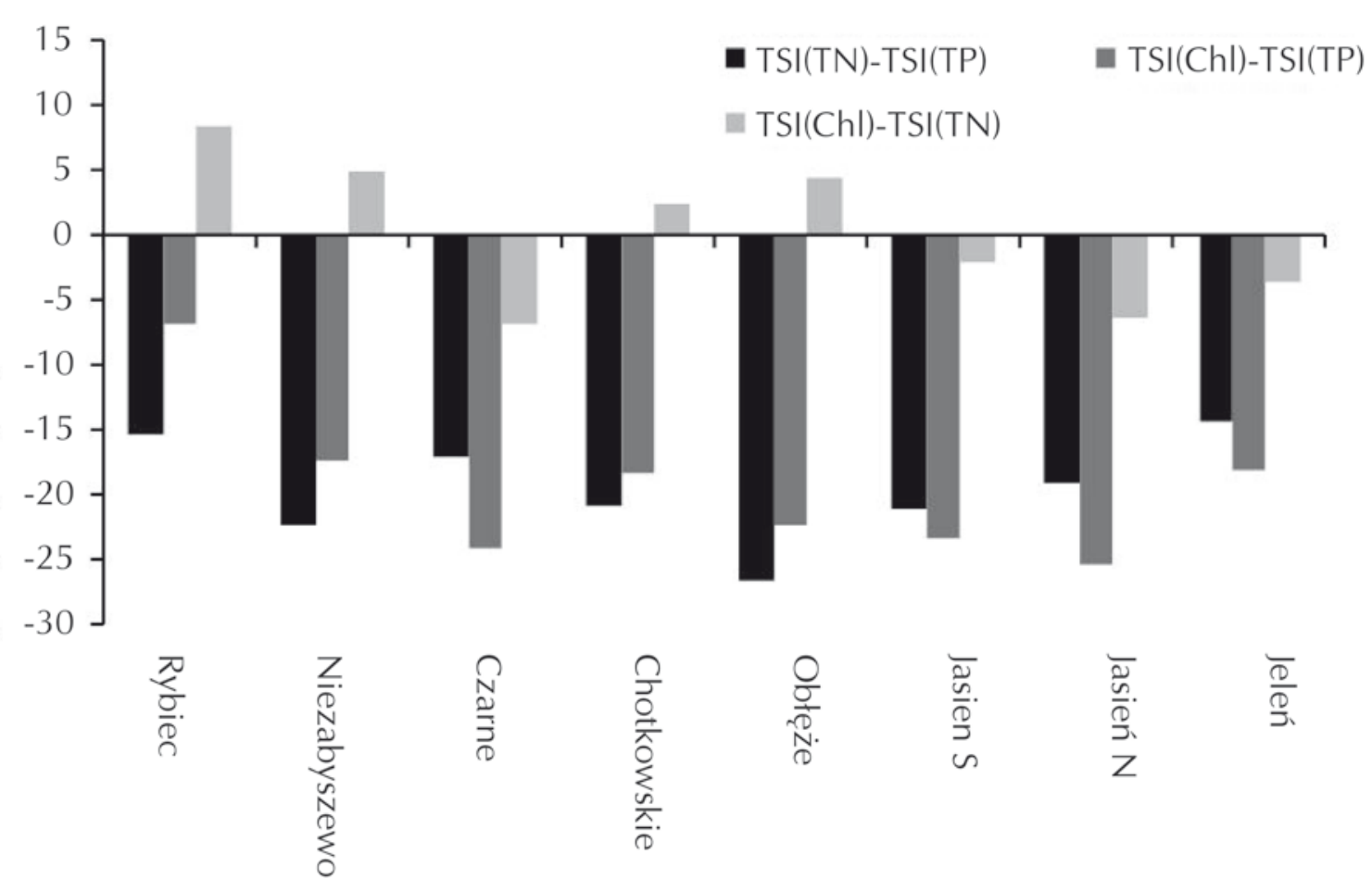

Fig. 5. Mean annual deviations of Carlson-type indices, based on monthly data from surface water

of about -14 for Lake Jeleń up to nearly -27 for Lake Obłęże. The fact that in each of the presented lakes the value of the index based on the chlorophyll $a$ concentration is lower than the value of the index related with the total phosphorus concentration suggests that there could be another factor limiting algal productivity (e.g. another nutrient, physical parameters). And actually (Fig. 5) for four of the analyzed lakes, namely Rybiec, Niezabyszewo, Chotkowskie and Obłęże, it is possible to imply nitrogen limitation. For each of these lakes, the TSI (Chl) - TSI(TN) varies between 1.5 (Lake Obłęże) and 8.4 (Lake Rybiec). Moreover, in the case of 6 lakes the TN/TP ratio was below 10 (Table 1) which suggests that $T N$ is the primary production limiting factor (Seip et al. 2000). In Lake Rybiec the ratio TN/TP was 10.4, and only in Lake Jelen was the ratio TN/TP in the range 10 to 17 (13.7) and suggests both TN and TP limitation of phytoplankton growth.

This hypothesis is supported by more detailed diagrams prepared for each lake (Fig. 6). In the diagrams the horizontal zero line is associated with nutrient limitation i.e. as points go above the zero axis, it would suggest an increasing possibility of $\mathrm{P}(\mathrm{N})$ limitation. Points lying to the right of the Y-axis indicate situations where the transparency is greater than expected from the TSI $(\mathrm{Chl})(\mathrm{TSI}(\mathrm{Chl})>\mathrm{TSI}(\mathrm{SD}))$. These deviations may occur if large particulates (blue-green algae) dominate, and transparency is less affected by the particulates, or if zooplankton grazing removes smaller particles and leaves only large forms. Points to the left of vertical line describe the situation where TSI(Chl) $<$ TSI(SD) and the low transparency is dominated by non-algal factors such as high concentrations of dissolved organic matter or small particles of nonalgal turbidity or colour (Carlson and Simpson 1996; Matthews et al. 2002; Wetzel 2001). Based on the diagrams (Fig. 6), in most of the analyzed lakes the factors limiting algal productivity could be the zooplankton grazing and relativly low - in comparison to phosphorus - nitrogen concentration in the water.

Only in the case of one lake i.e. Lake Czarne, is phytoplakton production probably limited by a physical factor, such as water transparency. This lake is on the border of being a dystrophic water body. Its catch- 

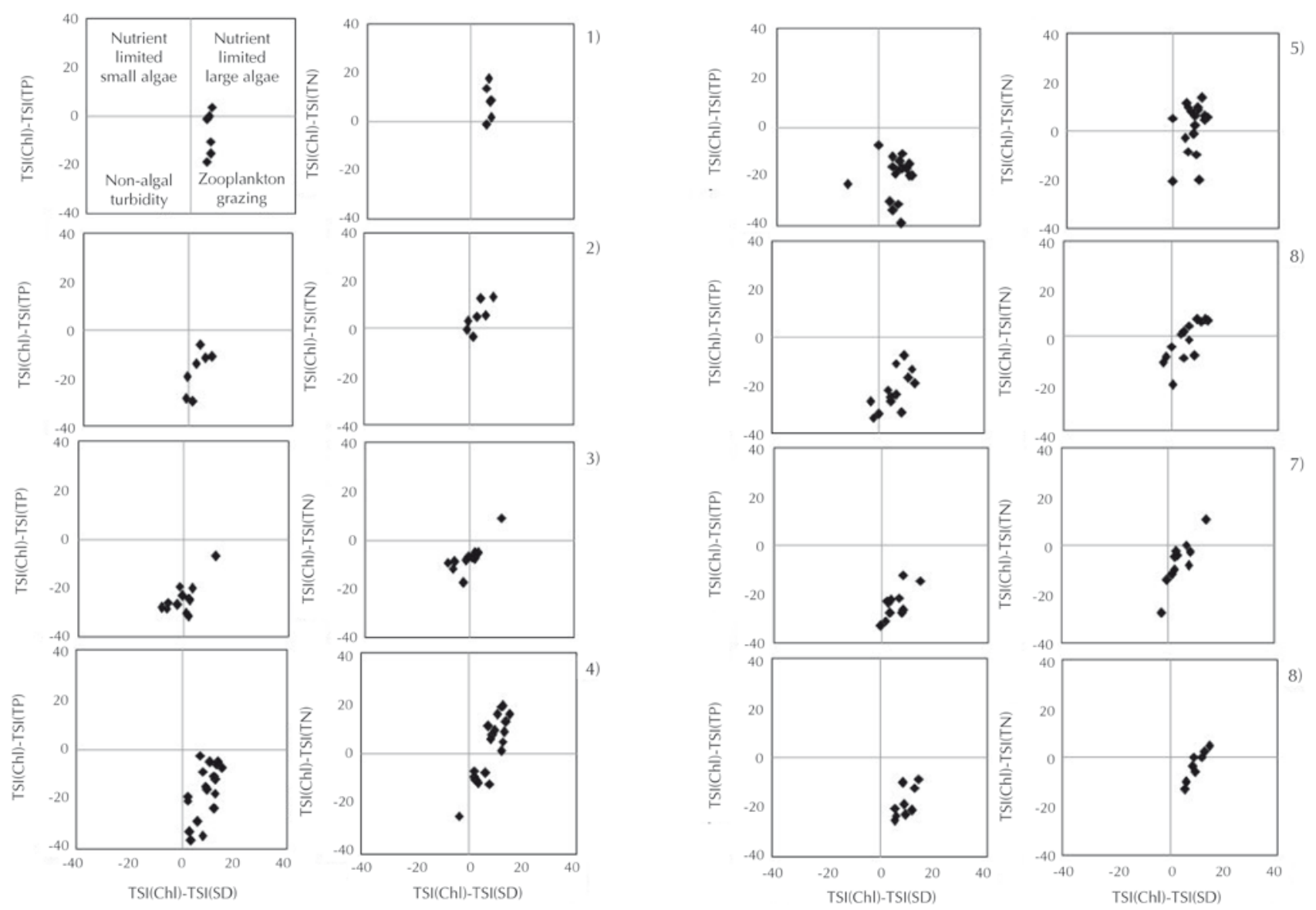

Fig. 6. Diagrams of deviations between Carlson-type indices; lakes: 1 - Rybiec, 2 - Niezabyszewo, 3 - Czarne, 4 - Chotkowskie, 5 Obłęże, 6 - Jasień S, 7 - Jasień N, 8 - Jeleń; squares in each diagram define the type of limiting factor (based on Carlson and Simpson 1996, Matthews et al, 2002)

ment basin is afforested and it is not threatened by anthropopressure. The annual $\mathrm{pH}$ value of this lake water is below 7 , and the presence of humic acids gives the water a slightly brownish colour.

Nitrogen limitation in lakes is recently more often observed and described in the literature (Havens 1995; Hong et al. 2008; Pełechata et al. 2006; Rekolainen et al. 2005; Schindler 2006), although phosphorus has been considered to be commonly the initial nutrient limiting factor for algal growth in lakes (Rekolainen et al. 2005; Wetzel 2001). When phosphorus is available in quantities adequate to support metabolism, nitrogen availability can become limiting. This limitation is often observed under eutrophic conditions. In the case of high phosphorus loading, planktonic utilization of nitrogen can exceed inputs and deplete nitrogen supplies in the trophogenic zone (Wetzel 2001).
Restriction of nitrogen supply from the environment to lake water, associated with several overlapping political and economic factors in Poland and other eastern-central European countries (i.e. drastically diminished use of mineral fertilizers in agriculture, diminished total area of farmland, increased use of catalytic converters in vehicles and limitations of emission from energy production) (Witek and Jarosiewicz 2009; Rekolainen et al. 2005) is probably the factor which promotes $\mathrm{N}$ limitation in the analyzed lakes. Rekolainen et al. (2005) described the fact that significant reduction in nitrogen emission within central European countries is most probably the main cause of the observed reduction in dissolved inorganic nitrogen in the Finnish lakes. Moreover, the authors suggest that this situation gives an indication that more lakes than earlier may have become nitrogen 
limited or limited both by nitrogen and phosphorus, at least during the growing season.

On the other hand, still high phosphorus concentration in the analyzed lakes, associated with both an uncontrolled wastewater system especially in rural areas (Lakes Rybiec and Obłęże, which lack any wastewater treatment plants in their immediate surroundings, are in fact direct receiving tanks of sewage and wastewater), and the internal supply of phosphorus from sediments (Jarosiewicz unpublished data), decrease the proportion of nitrogen to phosphorus and make nitrogen limitation more likely to occur.

\section{Acknowledgments}

The study was partially funded by MNiSW (Polish Ministry of Science and Higher Education) in the years 2008-2011 as a grant N N306 066434 .

\section{References}

Bajkiewicz-Grabowska E., 2007, Zróżnicowanie troficzne jezior - stan obecny, miejsce w klasyfikacji troficznej (Trophic diversity of lakes - present state, the place in trophic classification), [in:] Borowiak D. (ed.), Lakes of the Kashubian Landscape Park, KLUG, Gdańsk: 293-305 (in Polish, English summary).

Carlson R. E., 1977, A trophic state index for lakes, Limnol. Oceanogr. 22: 361-639.

Carlson R. E., 1991, Expanding the trophic state concept to identify non-nutrient limited lakes and reservoirs, [in]: Carpenter L. (ed.), Proc. of a national conference on enhancing the states' lake management programs, USEPA, Chicago: 59-71.

Carlson R.E., Simpson J., 1996, A coordinator's guide to volunteer lake monitoring methods, North American Lake Management Society, p. 96.

Dodds W. K., Jones J. R., Welch E. B., 1998, Suggested classification of stream trophic state: distributions of temperate stream types by chlorophyll, total nitrogen, and phosphorus, Water Res. 32: 1455-1462.

Havens K. E., 1995, Secondary nitrogen limitation in a subtropical lake impacted by non-point source agricultural pollution, Environ. Pollut. 89: 241-246.

Hong H. C., Wong M. H., Mazumder A., Liang Y., 2008. Trophic state, natural organic matter content, and disinfection by-product formation potential of six drinking water reservoirs in the Pearl River Delta, China, J. Hydrol. 359: 164-173.

Jarosiewicz A., Hetmański T., 2009, Sezonowa zmienność stężenia substancji biogenicznych w wodach jeziora Dobra (Pojezierze Pomorskie); poziom trofii jeziora (Seasonal changes in nutrients concentration in lake Dobra
(Pomeranian Lake District); trophic state of lake, Słupskie Pr. Biol. 6: 71-80 (in Polish).

Jeffrey S. W., Humphrey G. F., 1975, New spectrophotometric equation for determining chlorophyll a, b, c1 and c2, Biochem. Physiol. Pflanz. 167: 194-204.

Joniak T., Kuczyńska-Kippen N., 2008, Effect of aquatic macrophytes on water trophy of lowland water bodies in aspect of their surface differentiation, Teka Kom. Ochr. Kszt. Środ. Przyr - OL PAN 5A: 47-52.

Kratzer C. R., Brezonik P. L., 1981, A Carlson-type trophic state index for nitrogen in Florida Lakes, Water Res. Bull. 17: 713-715.

Kubiak J., 2003, The largest dimictic lakes of western Pomerania: trophic status, susceptibility to degradation and habitat condition for fish fauna. Rozprawy 214, AR Szczecin (in Polish with English summary)

Lenard T., Solis M., 2009, Trophic diversity of three deep lakes - Piaseczno, Rogoźno and Krasne - in the years 2006-2007 (Łęczna-Włodawa lake district), Teka Kom. Ochr. Kszt. Środ. Przyr - OL PAN 6: 162-169.

Matthews R., Hilles M., Pelletier G., 2002, Determining trophic state in Lake Whatcom, Washington (USA), a soft water lake exhibiting seasonal nitrogen limitation, Hydrobiologia 468: 107-121.

Marszelewski W., 2001, Jeziora Pojezierza Dobrzyńskiego (Lakes of the Dobrzyńskie Lakeland), UMK, Toruń, p. 139 (in Polish, English summary).

Pełechata A., Pełechaty M., Pukacz A., 2006, An attempt to the trop hic status assessment of the lakes of Lubuskie Lakeland, Limnol. Rev. 6: 239-246.

Pyka J. P., Zdanowski B., Stawecki K., Prusik S., 2007, Trends in environmental changes in the selected lakes of the Mazury and Suwałki Lakelands, Limnol. Rev. 2: 101-109.

Rekolainen S., Mitikka S., Vuorenmaa J., Johansson M., 2005, Rapid decline of dissolved nitrogen in Finnish lakes, J. Hydrol. 304: 94-102.

Seip K. L., Jeppesen E., Jensen J. P., Faafeng B., 2000, Is trophic state or regional location the strongest determinant for Chl-a/TP relationships in lakes?, Aquat. Sci. 62: 195204.

Schindler D. W., 2006, Recent advances in the understanding and management of eutrophication, Limnol. Oceanogr. 51(1, part 2): 356-363.

Wetzel R. G., 2001, Limnology. Lake and River Ecosystems, Academic Press, San Diego, California, p. 1006.

Witek Z., Jarosiewicz A., 2009, Long-term changes in nutrient status of river water, Pol. J. of Environ. Stud. 18: 1177-1184.

Zdanowski B., 1999, Eutrofizacja jezior Wigierskiego Parku Narodowego: zagrożenia i ocena (Eutrophication of the lakes of the Wigry National Park: threats and evaluation), [in:] Zdanowski B., Kamiński M., Martyniak A. (eds), Funkcjonowanie i ochrona ekosystemów wodnych na obszarach chronionych (Functioning and the protection of aquatic ecosystems on protected areas), IRS, Olsztyn: 261-278. 
